\title{
Internal Iliac Lymph Node
}

National Cancer Institute

\section{Source}

National Cancer Institute. Internal Iliac Lymph Node. NCI Thesaurus. Code C88142.

A lymph node located along the internal iliac artery. 